\title{
The Effect of Smasse In-Service Training on Performance of Mathematics in Selected Sendondary Schools in Kenya
}

\author{
Nyamwange Nyamari Dennis \\ Kyalo Benjamin Wambua \\ Opakas Peter
}

Department Of Educational Management And Policy Studies

School Of Education, Moi University - Kenya

doi: 10.19044/esj.2017.v13n10p169 URL:http://dx.doi.org/10.19044/esj.2017.v13n10p169

\begin{abstract}
Over the years performance of mathematics at secondary level has dropped significantly causing a major concern to society. It is against this background that this study sought to investigate the effect of Strengthening Mathematics and Sciences in Secondary Education, In-Service Education Training project on performance of mathematics at Kenya Certificate of Secondary Examinations, with regard to the subject content, pedagogy/methodologies, attitude and teaching-learning material. The study area was in Kisii Central District in Kisii County. The sample size comprised of 20 secondary schools, 41 mathematics teachers and 380 students. Both probability and nonprobability Sampling techniques were adopted to determine sample size. Qualitative data were collected through interview and document analysis. Questionnaires were used to collect quantitative data from students, teachers of mathematics and Mathematics Head of Departments. Quantitative data were analyzed by both descriptive and inferential statistics (chi-square). Qualitative analysis involved categorization and development of themes. The research found out that Strengthening Mathematics and Sciences Secondary Education, In-Service Education Training project had significantly improved performance of mathematics. The study established that Strengthening Mathematics and Sciences Secondary Education, In-Service Education Training has changed attitude of teachers and students, improved Pedagogical Content Knowledge and Teaching/Learning Materials, and thus some improvement in performance of mathematics. The study will be useful to the mathematics teachers in evaluating their work against the SMASSE INSET methodologies in relation to their performance. The study will also be useful to DQASO's for their supervision processes from one school to another. The findings should also
\end{abstract}


help proponents of SMASSE INSET project to review their curriculum especially to incorporate more content coverage to add to the mastery of content of the mathematics teachers. The study recommends for further research on the relevance of subject content knowledge acquired by secondary mathematics teachers in the teachers training colleges and universities.

Keywords: Smasse program, education, Kenya

\section{Introduction}

The study investigated the Effect of Strengthening Mathematics and Sciences in Secondary Education, In-Service Education Training (SMASSE INSET) project on performance of mathematics at Kenya Certificate of Secondary Examinations (KCSE), with regard to the Subject Content Knowledge (SCK), Pedagogical Content Knowledge (PCK)/Methodologies, Attitude (A) and Teaching-Learning Material (TLM). A great concern amongst Kenyans was the poor performance of students in mathematics at Kenya Certificate of Secondary Education. Andrew (2010) argued that there were constraints on in-service and pre-service teachers' performance when explaining concepts in mathematics. Charalombos (2010) opines that teacher knowledge is a major contributor to the structuring and delivering of mathematics lessons. Thus the concept of subject content knowledge which is a variable of SMASSE INSET determines efficiency of teaching-learning activities. SMASSE INSET project was conceived as an intervention measure to fix the problem of poor performance in mathematics and sciences at secondary schools in Kenya. In 1998, the SMASSE INSET project carried out a baseline study in the pilot districts, to find out the root cause of the poor performance or low grades in mathematics and sciences (SMASSE INSET, 1998). The study identified a number of problems which were dubbed 'the main problems which needed to be tackled'. There was the poor attitude of the teachers, the learners and key stakeholders. There was also the problem of inappropriate teaching methods and approaches coupled with poor utilization and distribution of school resources and then, there was poor content mastery by the teachers (MoEST, 1998). According to Schofield (1981), Shulman (1987) and Ball (1991), subject-matter knowledge is mathematics teacher's mathematics achievement. Ball (1991) and Shulman (1986) in Wong and Lai (2010) consider pedagogy content knowledge to be knowledge of representing and formulating the subject matter and making it comprehensible to students. 


\section{Statement of the Problem}

The introduction of an in-service programme, SMASSE INSET, in 1998, was to help solve the problem of mass failures in mathematics at KCSE by changing attitude of both mathematics teachers and students; improving SCK and PCK of teachers; and providing Teaching Learning Materials (Nui \& Wahome, 2006). Poor performance is blamed on the teacher knowledge content in the subject (Andrew, 2010). In the study conducted in South Africa on the factors contributing to poor performance in mathematics, it was discovered that outdated teaching practices and lack of basic content knowledge resulted in poor teaching standards (Andile \& Makgato, 2010).

\section{Purpose of the Study}

The study investigated the effect of SMASSE INSET project on the performance of mathematics at KCSE examinations in secondary schools in the Kisii Central district of Kisii County, Kenya.

\section{Objectives of the Study}

The specific objectives of the study were:

1. To examine the influence of SMASSE INSET pedagogical paradigms/ methodologies on the teaching and learning of mathematics in secondary schools.

2. To determine the influence of subject content covered in SMASSE INSET on the mastery of content of mathematics teachers.

3. To analyse teachers' and students' attitude of the relevance of SMASSE INSET in improving performance of mathematics.

4. To establish the influence of SMASSE INSET's teaching-learning materials on syllabus coverage in mathematics.

\section{Hypotheses}

The study was anchored on the following hypotheses:

Ho1- There is no statistically significant relationship between subject content covered in SMASSE INSET and mastery of content in mathematics teachers in Kisii Central district.

$\mathbf{H}_{\mathbf{0}}$ 2- There is no relationship between SMASSE INSET's teachinglearning materials on syllabus coverage in mathematics at secondary schools

$\mathbf{H}_{\mathbf{0}}$ 3: There is no significant relationship between students' attitude and performance in mathematics

\section{Conceptual Framework}

In Kenya, the main measure of performance in schools is examinations. Thus, examination performance is the output of an education 
system. The inputs include teachers (SCK, PCK, Attitude,), students and resources such as books, facilities among others. Consequently, performance will depend on the interactions of inputs. Kombo (2004) in Kombo and Tromp (2006) argues that if the interaction of inputs is healthy, then the output (performance) should be good and vice versa. The study came up with a model of SMASSE INSET components and performance. Thus, Performance of Mathematics is a function of the elements/parts of SMASSE INSET (pedagogy, SCK, attitude and TLM) as shown in the framework (figure 1).

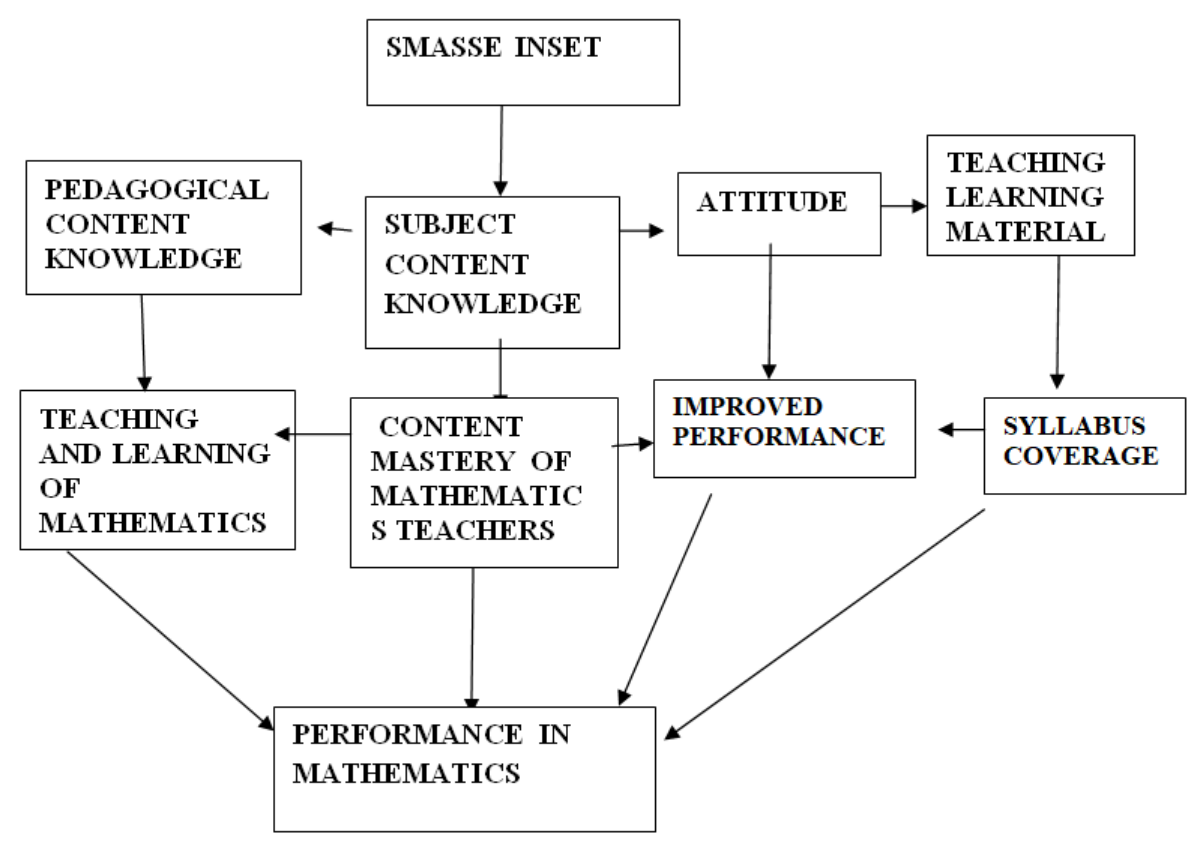

Figure 1: Conceptual Framework

$\mathrm{P}=\mathrm{f}\{\mathrm{SCK}, \mathrm{PCK}$ (PDSI, ASEI Lesson plan), AT, and TLM ...EVs $\}$

Where SCK is subject content knowledge; PCK, pedagogy content knowledge; AT is the attitude of teachers towards mathematics; TLM is teaching-learning materials; and EVs means other extraneous variables which influence performance in mathematics. PDSI means Plan-Do-SeeImprove; ASEI means Activity-Student-Experiment-Improvisation. Subject content knowledge is what is taught during the training. The model above shows the main pillars of this study and how various variables interact to produce results. That is, performance of mathematics is dependent on SCK, PCK, and attitude of the teacher and TLMs. Here, SMASSE INSET is the main independent variable and performance in mathematics (the dependent variable). In SMASSE INSET, the content covered includes the mathematics subject content knowledge, the pedagogy content knowledge such as PDSI 
paradigm and ASEI lesson plan among other aspects; and most important, change of attitude and the way teaching-learning materials can be combined to improve teaching.

Nonetheless, performance may be affected by some other extraneous variables such as entry behaviour of students, school traditions and students and teachers' determination. All of the variables incorporated in the framework have direct or indirect influence on performance in mathematics. These variables are the students, entry behaviour, attitude of both teachers and students towards mathematics, school traditions or routines and determinations of both students and teachers to do well, and the resources available which differ from one institution to another.

\section{Methodology}

\section{Sampling Methods and Participants}

Sixty three secondary schools in Kisii Central district which included all the public and private secondary schools in Kisii Central district with a student population of 35 304; 136 mathematics teachers; 63 Mathematics H.O.Ds; 63 Examinations masters/Director Of Studies (DOS); 63 principals; and examinations coordinator-DEO's office constituted the target population. Stratified random sampling technique was employed to categorize schools into boys' boarding schools, girls' boarding schools, mixed day schools and private schools. Purposeful sampling was used to select Kisii High school because of its role as the SMASSE INSET centre. Simple random sampling was used to select twenty schools (about 30\% of the total number of 63) in the district. At the school level, the study used stratified sampling to classify students into form one, two, three and four. Then simple random sampling was used to select students in each form, and obtained a sample of three hundred and eighty 380. Two mathematics teachers were randomly selected from each of the twenty sampled school except cases of schools which had only one mathematics teacher in which case it was compensated with teachers from other schools which had more teachers thus sampling forty mathematics teachers. All mathematics H.O.Ds, Examinations H.O.Ds/masters/D.O.S and principals of the twenty sampled schools formed the sample population.

The number of students sampled out from each school depended on the ratio of the school population to the total student population in the district. Then depending on the number of students in each class, sampling was done proportionately. In the case of mixed schools, stratified random sampling was used to categorize students into girls and boys according to the ratios of girls to boys in each selected school. 


\section{Research Instruments}

This study employed questionnaires, interviews schedules and content analysis to collect data for the study. The questionnaires contained only closed ended questions. There were three categories of questionnaires, 380 for the students, 41 for mathematics teachers and 20 for the H.O.D Mathematics of the selected schools. The study adopted the five points Likert scale in rating of questions. Such questions generated five responses as Strongly Agree (SA), Agree (A), Undecided (U), Disagree (D) and Strongly Disagree (SD). Two forms of scoring the questionnaire items were used depending on the nature of the questions. Responses were scored as $5,4,3,2$, and 1 respectively in a sliding scale for positive responses and the reverse for negative responses. The study adopted unstructured interviewing techniques. Unstructured interviews were used to get information from the SMASSE INSET Centre Officials. They generated vital information on the TLM and the training processes. The trend of KCSE national examinations performance in mathematics at the district level for various years for the period ranging from 1996 to 2009 was established by studying and analysing the data at the DEO's office. More data on performance in mathematics was obtained at school level at the HOD Examinations' or DOS' office. Further document analysis involved finding out from SMASSE INSET centre the number of mathematics teachers who had trained and those who had not trained in the district by the time the study was undertaken. This information was obtained from the district SMASSE INSET office at the District Training Centre. The information helped in determining the attitude of teachers who started the training but dropped out. Through document analysis, the study was able to obtain accurate information of past events pertaining SMASSE INSET and KCSE performance.

\section{Data Analysis Techniques}

Both quantitative and qualitative data were collected. Inferential statistics, (Chi-square $\left(\mathrm{X}^{2}\right)$ was used to measure relationship between the independent and dependent variables. The Chi-square was also used to measure the validity of null hypotheses based on selected variables. The hypotheses tested were: there is no significant relationship between pedagogical paradigms learned in SMASSE INSET and performance of mathematics at secondary schools in Kisii central district; there is no statistically significant relationship between subject content covered in SMASSE INSET and mastery of content of mathematics teachers in Kisii Central district; there is no statistically significant relationship between the teachers' attitude of SMASSE INSET and performance of mathematics at secondary schools in Kisii Central district; and there is no relationship between SMASSE INSET's teaching-learning materials and syllabus 
coverage in mathematics at secondary schools. Qualitative data were categorized and developed into themes.

\section{Ethical Considerations}

Responses to questions by respondents were treated with high levels of confidentiality. Names of students, teachers or individual schools were not recorded or mentioned anywhere in the research document. Consequently, respondents were not allowed to write their names on the questionnaire forms. Permission was sought out at all levels before respondents gave their responses or before the researcher accessed particular information. That is, no information was accessed without the consent of the concerned authorities or without consent of individuals.

\section{Summary of Findings}

The first objective of this study was to determine whether SMASSE INSET pedagogical paradigms/ methodologies had improved the teaching and learning of mathematics in secondary schools. Table 1 presents the analysis:

Table 1: Responses on PCK

\begin{tabular}{|c|c|c|c|c|c|c|c|}
\hline STUDENTS' RESPONSES & \multicolumn{2}{|c|}{ A } & \multicolumn{2}{|c|}{$\mathrm{U}$} & \multicolumn{2}{|c|}{$\mathrm{D}$} & $\mathrm{N}$ \\
\hline & $\mathrm{F}$ & $\%$ & $\mathrm{~F}$ & $\%$ & $\mathrm{~F}$ & $\%$ & \\
\hline $\begin{array}{c}\text { Teachers use teaching aids in } \\
\text { class }\end{array}$ & 269 & 70.8 & 35 & 9.2 & 76 & 20 & 380 \\
\hline $\begin{array}{l}\text { Teachers involve us in practical } \\
\text { work in mathematics }\end{array}$ & 238 & 62.7 & 46 & 12.1 & 96 & 25.2 & 380 \\
\hline $\begin{array}{c}\text { MATHEMATICS TEACHERS } \\
\text { RESPONSES }\end{array}$ & & & & & & & \\
\hline $\begin{array}{l}\text { SMASSE INSET has helped me } \\
\text { change my teaching } \\
\text { methodologies in mathematics }\end{array}$ & 39 & 95.1 & 1 & 2.4 & 1 & 2.4 & 41 \\
\hline $\begin{array}{l}\text { I use ASEI lesson plan and is } \\
\text { convenient in the teaching and } \\
\text { learning of mathematics }\end{array}$ & 24 & 58.5 & 5 & 12.2 & 12 & 29.3 & 41 \\
\hline $\begin{array}{l}\text { The PDSI principle has proved } \\
\text { to be a vital tool in the teaching } \\
\text { and learning of mathematics }\end{array}$ & 33 & 80.5 & 2 & 4.9 & 6 & 14.6 & 41 \\
\hline H.O.D MATHEMATICS’ & & & & & & & \\
\hline
\end{tabular}




\begin{tabular}{|c|c|c|c|c|c|c|c|}
\hline RESPONSES & & & & & & & \\
\hline $\begin{array}{c}\text { Teachers use locally available } \\
\text { materials to make T/L aids as } \\
\text { advocated by ASEI principle }\end{array}$ & 18 & 90 & 1 & 05 & 1 & 05 & 20 \\
\hline $\begin{array}{c}\text { Teachers use the principles of } \\
\text { PDSI and ASEI in preparing } \\
\text { their lessons }\end{array}$ & 11 & 55 & 4 & 20 & 5 & 25 & 20 \\
\hline $\begin{array}{c}\text { SMASSE INSET has improved } \\
\text { the professionalism and } \\
\text { methodologies in the } \\
\text { teaching and learning of } \\
\text { mathematics }\end{array}$ & 19 & 95 & 0 & 0 & 1 & 5 & 20 \\
\hline
\end{tabular}

KEY:F- Frequency; \% - percentage; and $\mathrm{N}$ - total number of respondents

According to the analysis, ninety five percent (95.1\%) of mathematics teachers agreed that SMASSE INSET has helped them to change their teaching methodologies. Out of a maximum of $100 \%, 58.5 \%$ scored on the use and convenience of Activity- Student-ExperimentImprovisation (ASEI) principle; and 80.5\% accepted Plan-Do-See-Improve (PDSI) principle as playing a vital role in the teaching and learning of mathematics in class. Ninety five percent (95\%) of the teachers interviewed accepted that SMASSE INSET has improved their professionalism in the teaching and learning of mathematics. Therefore SMASSE INSET remains to be an important in- service training which shapes professionalism in the teaching profession.

The study examined the relationship between subject content and mastery of content using chi-square test: Ho1- There is no statistically significant relationship between subject content covered in SMASSE INSET and mastery of content of mathematics teachers in Kisii Central district. The chi-square outcome is presented in table 2:

Table 2 Chi Square of PCK

\begin{tabular}{|l|l|l|l|}
\hline & Value & Df & $\begin{array}{l}\text { Asymp. } \\
\text { Sig. (2-sided) }\end{array}$ \\
\hline $\begin{array}{l}\text { Pearson } \\
\text { Chi-Square }\end{array}$ & $922.075^{\mathrm{a}}$ & 16 & .000 \\
\hline Likelihood Ratio & 794.241 & 16 & .000 \\
\hline Linear-by-Linear Association & 341.304 & 1 & .000 \\
\hline N of Valid Cases & 380 & & \\
\hline
\end{tabular}

5 cells (20.0\%) have expected count less than 5 . The minimum expected count is 1.82 
The $\mathrm{X}^{2}$ value is greater than the critical value of 1.82 at $16 \mathrm{df}$ and 0.05 level of significance. Thus the null hypothesis was rejected. The findings of this study were in line with Wong and Lai (2010) who opine that the way knowledge is presented and formulated influences the process of learning. The results revealed that the pedagogical content knowledge learned in SMASSE INSET was being applied in schools and it was appreciated by both the teachers and the students.

The second objective of the study was to determine whether the subject content covered in SMASSE INSET has improved mastery of content of mathematics teachers. Table 3 analyses students responses in relation to mastery of subject content and content covered by teachers.

Table 3: Responses on SCK.

\begin{tabular}{|c|c|c|c|c|c|c|c|}
\hline \multirow{2}{*}{ STUDENTS’ RESPONSES } & \multicolumn{2}{|c|}{ A } & \multicolumn{2}{|c|}{ U } & \multicolumn{2}{|c|}{$\mathrm{D}$} & \multirow[t]{2}{*}{$\mathrm{N}$} \\
\hline & $\mathrm{F}$ & $\%$ & $\mathrm{~F}$ & $\%$ & $\mathrm{~F}$ & $\%$ & \\
\hline $\begin{array}{l}\text { Teachers explain well all } \\
\text { concepts in mathematics }\end{array}$ & 269 & 70.8 & 37 & 9.7 & 74 & 19.5 & 380 \\
\hline $\begin{array}{l}\text { All the mathematics topics in } \\
\text { the syllabus are taught }\end{array}$ & 210 & 55.3 & 38 & 10 & 132 & 34.7 & 380 \\
\hline $\begin{array}{l}\text { Teachers get problems } \\
\text { explaining some mathematics } \\
\text { topics }\end{array}$ & 125 & 32.9 & 51 & 13.4 & 204 & 53.7 & 380 \\
\hline $\begin{array}{l}\text { Teachers avoid answering } \\
\text { mathematics questions }\end{array}$ & 59 & 15.5 & 48 & 12.6 & 273 & 71.8 & 380 \\
\hline $\begin{array}{c}\text { MATHEMATICS } \\
\text { TEACHERS’ RESPONSES }\end{array}$ & & & & & & & \\
\hline $\begin{array}{l}\text { I get problems handling some } \\
\text { of the topic }\end{array}$ & 18 & 43.9 & 3 & 7.3 & 20 & 48.8 & 41 \\
\hline $\begin{array}{l}\text { There are topics I was never } \\
\text { taught and I never teach }\end{array}$ & 11 & 26.7 & 4 & 9.8 & 26 & 61.4 & 41 \\
\hline $\begin{array}{l}\text { SMASSE INSET has made } \\
\text { me teach some of the topics I } \\
\text { never used to teach }\end{array}$ & 24 & 58.5 & 4 & 9.8 & 13 & 31.7 & 41 \\
\hline $\begin{array}{l}\text { H.O.D MATHEMATICS' } \\
\text { RESPONSES }\end{array}$ & & & & & & & \\
\hline There are topics in the & 20 & 100 & 0 & 00 & 0 & 00 & 20 \\
\hline
\end{tabular}




\begin{tabular}{|c|c|c|c|c|c|c|c|}
\hline $\begin{array}{c}\text { syllabus which give teachers } \\
\text { problems }\end{array}$ & & & & & & & \\
\hline $\begin{array}{c}\text { SMASSE INSET has helped } \\
\text { teachers to cover topics they } \\
\text { never used to cover }\end{array}$ & 15 & 75 & 1 & 5 & 4 & 20 & 20 \\
\hline $\begin{array}{c}\text { SMASSE INSET syllabus } \\
\text { topic coverage is adequate }\end{array}$ & 12 & 60 & 1 & 5 & 7 & 35 & 20 \\
\hline
\end{tabular}

KEY: F - Frequency; $\mathrm{N}$ - total Number of respondents

The results of the study revealed that $70.8 \%$ of the students agreed that teachers explain well all concepts in mathematics and $19.5 \%$ did not accept that teachers explain well all concepts in mathematics; $55.3 \%$ of the students agreed that all topics in the syllabus are covered while $34.70 \%$ were in the contrary opinion; and $15.50 \%$ of the students agreed that teachers avoid answering questions in class while $71.80 \%$ of the students objected. $43.90 \%$ of the teachers sampled agreed that they get problems in handling some of the topics while $48.80 \%$ of them disagreed of any difficulties in handling any topic; $58.50 \%$ agreed that SMASSE INSET has made them teach topics they never used to teach while $31.70 \%$ disagreed; and $26.86 \%$ agreed that there are topics they were never taught and they never teach while $63.40 \%$ disagreed with the statement. Hundred percent (100\%) of the HODs agreed that some topics give problems to teachers; $75 \%$ acknowledged SMASSE INSET' has helped to cover topics they never used to cover while $20 \%$ objected; and $60 \%$ of HODs felt that SMASSE INSET topic coverage was adequate while $35 \%$ felt the contrary. These findings reveal that SMASSE INSET has not fully achieved its objective to improve mastery of content of mathematics teachers. Thus there is every need to look at ways of achieving this objective.

A Chi Square test was computed to test the hypothesis that there is no statistically significant relationship between subject content covered in SMASSE INSET and mastery of content of mathematics teachers in Kisii Central district.

Table 4 : Chi-Square of SCK

\begin{tabular}{|c|c|c|c|}
\hline & Value & Df & Asymp. Sig. (2-sided) \\
\hline Pearson Chi-Square & $27.195 \mathrm{a}$ & 3 & .000 \\
\hline Likelihood Ratio & 85.415 & 3 & .000 \\
\hline $\begin{array}{c}\text { Linear-by-Linear } \\
\text { Association }\end{array}$ & 214.802 & 1 & .000 \\
\hline N of Valid Cases & 1781 & & \\
\hline
\end{tabular}

a. 0 cells $(.0 \%)$ have expected frequencies less than 5 . The minimum expected cell frequency is 10.3 . 
The $\mathrm{X}^{2}$ value is greater than the critical value of 10.3 at $3 \mathrm{df}$ and 0.05 level of significance. Thus the null hypothesis was rejected. This means that there is a statistically significant relationship between subject content covered in SMASSE INSET and mastery of content of mathematics teachers in Kisii Central district. Thus, SCK covered in SMASSE INSET is very vital in influencing mastery of mathematics teachers and finally performance of mathematics at KCSE. However, the findings showed that for the whole SMASSE INSET ten (10) topics out of sixty (60) topics from the secondary mathematics syllabus were covered. The whole training spans for four calendar years, a total of four cycles and each cycle covered in each calendar year.

The third objective of the study was to analyse teachers' and students' attitude of SMASSE INSET in improving performance of mathematics. Table 5 presents the findings on students, teachers and HODS attitude towards SMASSE INSET.

Table 5: Responses of students, teachers and HODs concerning attitude

\begin{tabular}{|c|c|c|c|c|c|c|c|}
\hline \multirow{2}{*}{ STUDENTS } & \multicolumn{2}{|c|}{ A } & \multicolumn{2}{|c|}{ U } & \multicolumn{2}{|c|}{ D } \\
\cline { 2 - 7 } & $\mathrm{F}$ & $\%$ & $\mathrm{~F}$ & $\%$ & $\mathrm{~F}$ & $\%$ & \\
\hline $\begin{array}{c}\text { Mathematics is } \\
\text { applicable to real life } \\
\text { situations }\end{array}$ & 380 & 100 & 0 & 00 & 0 & 00 & 380 \\
\hline $\begin{array}{c}\text { Mathematics is an } \\
\text { important subject in } \\
\text { my future career }\end{array}$ & 365 & 96.1 & 8 & 2.1 & 7 & 1.8 & 380 \\
\hline $\begin{array}{c}\text { Mathematics is one of } \\
\text { my best subjects }\end{array}$ & 298 & 78.5 & 24 & 6.3 & 58 & 15.3 & 380 \\
\hline $\begin{array}{c}\text { It is interesting doing } \\
\text { mathematics }\end{array}$ & 342 & 90 & 17 & 4.5 & 21 & 5.5 & 380 \\
\hline $\begin{array}{c}\text { MMASSE INSET has } \\
\text { no effect on the } \\
\text { performance of } \\
\text { mathematics }\end{array}$ \\
$\begin{array}{c}\text { improved performance } \\
\text { of mathematics in my } \\
\text { school }\end{array}$
\end{tabular}




\begin{tabular}{|c|c|c|c|c|c|c|c|}
\hline $\begin{array}{l}\text { SMASSE INSET has } \\
\text { made students to } \\
\text { change their attitude } \\
\text { positively towards } \\
\text { mathematics }\end{array}$ & 26 & 63.4 & 8 & 19.5 & 7 & 17.1 & 41 \\
\hline \multicolumn{8}{|c|}{ HOD MATHEMATICS } \\
\hline $\begin{array}{l}\text { SMASSE INSET has } \\
\text { positively contributed } \\
\text { to performance of } \\
\text { mathematics in my } \\
\text { school }\end{array}$ & 16 & 80 & 2 & 10 & 2 & 10 & 20 \\
\hline $\begin{array}{l}\text { Teachers are positive } \\
\text { about SMASSE } \\
\text { INSET Project }\end{array}$ & 16 & 80 & 2 & 10 & 2 & 10 & 20 \\
\hline
\end{tabular}

KEY:F - Frequency; \% - Percentage; $\mathrm{N}$ - total Number of respondents

The results of content analysis at the SMASSE INSET centre revealed that teachers are unable to complete the training because of what they term mistreatment by the trainers. However, results from the questionnaires revealed that students generally know mathematics is important in their future careers and is applicable to real life situations. Teachers also showed a positive change towards the training and agreed that SMASSE INSET has improved performance of mathematics in their schools and made students to change their attitude towards mathematics.

The null hypothesis that "there is no significant relationship between students' attitude and performance of mathematics" was rejected. In other words, there was a significant relationship at 5\% significance level between attitude and performance of mathematics $\left(X^{2}=693.923, d f=4, p=.000\right)$.

Table 6: Chi Square of Students' attitude

\begin{tabular}{|c|c|c|c|}
\hline & Value & Df & Asymp. Sig. (2-sided) \\
\hline Pearson Chi-Square & $693.923^{\mathrm{a}}$ & 4 & .000 \\
\hline Likelihood Ratio & 851.415 & 4 & .000 \\
\hline Linear-by-Linear Association & 614.802 & 1 & .000 \\
\hline N of Valid Cases & 1781 & & \\
\hline
\end{tabular}

0 cells $(.0 \%)$ have expected count less than 5 . The minimum expected count is 5.35 .

The fourth objective of the study was to determine whether SMASSE INSET had improved teaching-learning materials and syllabus coverage in mathematics. The outcome for this objective is presented in Table 7: 
Table 7: Responses from students, teachers and Mathematics HODs on TLMs

\begin{tabular}{|c|c|c|c|c|c|c|c|}
\hline \multirow[t]{2}{*}{ STUDENTS } & \multicolumn{2}{|c|}{ A } & \multicolumn{2}{|c|}{$\mathrm{U}$} & \multicolumn{2}{|c|}{$\mathrm{D}$} & \multirow[t]{2}{*}{$\mathrm{N}$} \\
\hline & $\mathrm{F}$ & $\%$ & $\mathrm{~F}$ & $\%$ & $\mathrm{~F}$ & $\%$ & \\
\hline $\begin{array}{l}\text { Enough books and other } \\
\text { materials help cover syllabus in } \\
\text { time }\end{array}$ & 312 & 82.1 & 10 & 2.6 & 58 & 15.3 & 380 \\
\hline $\begin{array}{l}\text { Teachers involve us to make } \\
\text { teaching learning aids }\end{array}$ & 279 & 73.4 & 23 & 6.1 & 78 & 20.5 & 380 \\
\hline \multicolumn{8}{|c|}{ MATHEMATICS TEACHERS } \\
\hline $\begin{array}{l}\text { SMASSE INSET has helped to } \\
\text { improvise teaching/learning } \\
\text { materials making it easier to } \\
\text { cover the syllabus }\end{array}$ & 35 & 63.4 & 2 & 4.9 & 4 & 9.7 & 41 \\
\hline $\begin{array}{l}\text { SMASSE INSET resources help } \\
\text { me in syllabus coverage }\end{array}$ & 22 & 53.6 & 3 & 7.3 & 16 & 39 & 41 \\
\hline $\begin{array}{c}\text { Adequate teaching/learning } \\
\text { materials have boosted syllabus } \\
\text { coverage in my school }\end{array}$ & 30 & 73.1 & 2 & 4.8 & 9 & 21.9 & 41 \\
\hline \multicolumn{8}{|c|}{ HOD MATHEMATICS } \\
\hline $\begin{array}{l}\text { SMASSE INSET has influenced } \\
\text { the number of teaching learning } \\
\text { materials in our department }\end{array}$ & 19 & 95 & 0 & 00 & 1 & 05 & 20 \\
\hline $\begin{array}{l}\text { SMASSE INSET project has } \\
\text { achieved one of its goal of } \\
\text { providing T/L resources }\end{array}$ & 15 & 75 & 3 & 15 & 2 & 10 & 20 \\
\hline $\begin{array}{l}\text { There are adequate } \mathrm{T} / \mathrm{L} \text { materials } \\
\text { in the department }\end{array}$ & 12 & 60 & 0 & 00 & 8 & 40 & 20 \\
\hline $\begin{array}{l}\mathrm{T} / \mathrm{L} \text { materials in the department } \\
\text { have facilitated syllabus coverage }\end{array}$ & 18 & 90 & 1 & 05 & 1 & 05 & 20 \\
\hline
\end{tabular}

KEY: F - Frequency; N - total Number of respondents

Analysis revealed that $82.11 \%$ of the students agreed that enough books and other materials helped them cover syllabus in time while $73.42 \%$ confirmed that teachers involved them in making teaching learning aids. $85.37 \%, 53.66 \%$ and $73.17 \%$ of the teachers agreed that SMASSE INSET has helped them to improvise TLM, with resources and have 
adequate TLM respectively, which have helped them in syllabus coverage. $95 \%$ and $75 \%$ of the HODs acknowledged that SMASSE INSET has influenced TLM in their departments and achieved its goal of providing T/L resources respectively. Sixty percent (60\%) of them accepted that there are adequate TLM in their departments while 90\% agreed that TLM have facilitated syllabus coverage. SMASSE INSET had improved TLM and syllabus coverage in mathematics. Wong and Lai (2010) reported that teaching/learning materials (which include textbooks, classrooms, teaching aids- chalk, board ruler and protractor, stationeries and laboratories) affect academic performance of learners.

To test the hypothesis that there is no statistically significant relationship between SMASSE INSET's teaching-learning materials and syllabus coverage in mathematics at secondary schools, Chi Square tests were computed at $5 \%$ significance level and the null hypothesis was rejected. Consequently, it was concluded that there was a significant relationship between TLM in mathematics and syllabus coverage at secondary schools. The adequate TLM particularly teaching aids were credited to SMASSE INSET project.

\section{Conclusion}

The study investigated the effects of SMASSE INSET on performance of mathematics in Kisii Central District. It particularly looked at the Pedagogical Content Knowledge (PCK), Subject Content Knowledge (SCK), Attitude and Teaching-Learning Materials (TLM) as components of SMASSE INSET. The findings showed that $82 \%$ of the respondents agreed that SMASSE INSET has improved the teaching and learning of mathematics. The study also wanted to find out whether SMASSE INSET has changed the attitude of students towards mathematics and teachers toward the in-service training.

A positive change of attitude in both cases was recorded. On the aspect of TLM it was generally credited to SMASSE IINSET. SMASSE INSET greatly and positively influenced TLMs in the departments to which HODs agreed $100 \%$.

The other component of the study was the SCK. The findings of the study revealed that almost half of the sampled teachers had problems handling particular topics in the syllabus. This implies that SMASSE INSET has done well in the other three aspects and poorly in SCK. In the analysis of the topics covered in SMASSE INSET for the four cycles, only ten (10) out of sixty (60) topics covers SCK, the other fifty (50) topic areas are pedagogical. It was also found that the three components of SMASSE INSET viz avis PCK, TLM and attitude are closely linked and PCK greatly influences the other two. 
SCK is also closely related to pedagogy, and thus the conceptual framework used in this study suffices that:

$\mathrm{P}=\mathrm{f}$ \{SCK, PCK (PDSI, ASEI Lesson plan), Attitude, and TLM ...EVs\}.

Therefore, performance in mathematics is the function of SCK, PCK, Attitude and TLMs. These findings agree with Andile and Makgato (2006) who asserted that subject content knowledge is important in determining effective delivery of teachers. Ball et al (2001) opined that PCK is practical knowledge of teaching which blends content and pedagogy. Southwell and White (2010) argued that the experiences of pre-service teachers influence the formation of attitudes which in turn influence classroom practice.

Kitao (2011) asserted that materials are the centre of instruction and one of the most important influences of what is going on in the classroom. Consequently, the study concludes that, the negligibly unnoticed improvement index of mathematics performance in Kisii Central District is due to PCK, SCK, Attitude change and TLM components of SMASSE INSET. However, the inadequate SCK of mathematics teachers in the district, which has not been covered properly by SMASSE INSET, has negatively affected the effects of SMASSE INSET on performance of mathematics.

\section{Recommendations}

The study recommends that SMASSE INSET includes more mathematics subject content relevant to secondary syllabus in the topics of discussion. This is because the teachers sampled agreed that they get problems in handling some of the topics and HODs felt that SMASSE INSET topic coverage was inadequate.

The study also recommends that the INSET trainers should be picked from the SMASSE INSET headquarters or other districts so that the issue of do as I say and not as I do does not arise. Teachers had claimed that the trainers had not implemented the SMASSE INSET principles in their schools yet they wanted the trainees to implement those principles. Others felt there was witch hunting of trainees by their neighbouring school trainers. This is illustrated by the letter trainees received from the DEO.s office copied to TSC.

Further recommendation is that Teachers training colleges to incorporate in the training more subject content relevant to the secondary level syllabus. This is because a bigger proportion of the teacher had problems explaining some concepts in the syllabus. This is also supported by Sessional Paper No.1 of 2005, which opines that secondary teacher training combines teaching methodology and subject mastery, a system which compromises both the subject content and methodology; and Andile and 
Makgato (2006) found out that educators had difficulties with certain sections of the content they taught.

The study suggests that the PCK and the SCK to be separated from each other during the pre-service training of the teachers such that specific duration is assigned to SCK and PCK respectively.

\section{References:}

1. Andile, M., \& Makgato, M .(2010). Factors Associated with High School learners' Poor Performance: A Spotlight on Mathematics and Physical Science, South African Journal of Education, 26(2),253266.

2. Ball, D. L.(1991). 'Research on teaching mathematics: Making subject matter knowledge part of the equation'. In J. Brophy (Ed.), Advances in research on teaching,_2, 1 - 48. Greenwich, CT: JAI Press.

3. Charalombos, Y.C. (2010). Mathematics Knowledge for teaching and Task Unfolding: An Exploratory Study, The Elementary School Journal, 110(3)

4. Cole, G. (2002).Personnel and Human Resource, (5 $5^{\text {th }}$ ed.), Ashford Colour Press, Gasport , Hants, Great Britain.

5. Farrant, J.S. (2005).Principles and Practice of Education, sage publishers, Los Angeles.

6. Fasokun, T.(2005). The Psychology of Adult Learning in Africa: African Perspective on Adult Learning, David Langhan, Cape.

7. Hammersley, M. (2007). Educational Research and Evidence-Based Practice, Sage Publications, Los Angeles.

8. Izs’ak A. (2010).Measuring Middle Grade Teachers’ Understanding of Rational Numbers with Mixture: Rasch model, The Elementary School Journal, 110(3), university of Chicago.

9. Jegede, O., Taplin, M., \& Chan, S. (2000).Trainee Teachers' Perception of their knowledge about expert teaching, Educational Research, 42(3), 287-308.

10. Kanja, C., Iwasaki, H., Baba, T., \& Uenda, A. (2001). For the Reform of Mathematics Education in Kenyan Secondary Schools, Journal of International Development and Cooperation, 7(1), 67-75

11. Kate, J. (2006). Professional studies: Primary Phase, Learning Matters Limited, UK.

12. Kimalu, K. P (2001).Education Indicators in Kenya, KPPRA, Nairobi, Kenya

13. KNEC (1998),KCSE Examinations Results, MoEST, Nairobi, Kenya. 
14. Kombo, D.K., \& Tromp, D. (2006). Proposal and Thesis Writing, an Introduction, Paulines Publications Africa, Nairobi, Kenya.

15. Nui, W.N., \& Wahome, A.N (2006). SMASSE PROJECT, Tsukuba Journal of Educational Study in Mahematics, 25(1)

16. Penso, S. (2002). Pedagogical content knowledge: How do student teachers identify and describe the causes of their pupils learning difficulties. Asia-Pacific Journal of Teacher Education, 30(1), 25-37.

17. Philias,

O. Y., $\&$ Kennedy, O.O.(2010). Teaching/Learning Resources and Academic Performance in Mathematics in Secondary School in Bondo District of Kenya, Asian Social Science, 6(12); December. 2010.

18. Republic of Kenya (1969) Development Plan (1969-1973), Nairobi, Kenya

19. Richard., A. K. (1995) Understanding Psychology, New York.

20. Shulman, L. (1986). Those Who Understand, Knowledge Growth in Teaching. Educational Researcher, 15:4-14.

21. Southwell, B., Allan, L., \& White, A.L. (2010). Attitudes versus Achievement in Pre- Service Mathematics Teacher Education, Sydney, Australia

22. Tak-wah, Wong., \& Yiu-chi Lai (2009), Exploring Factors Affecting Mathematics Teaching Effectiveness among Pre-Service Primary Mathematics Student- Teachers. 